Bangladesh J. Plant Taxon. 24(1): 39-47, 2017 (June)

(C) 2017 Bangladesh Association of Plant Taxonomists

\title{
MORPHOLOGICAL VARIABILITY OF EVERGREEN OAKS (QUERCUS) IN TURKEY
}

\author{
Yilmaz Aykut*, Uslu Emel ${ }^{1}$ and Babaç M. Tekin ${ }^{1}$ \\ Department of Molecular Biology and Genetics, Faculty of Science and Arts, \\ Uşak University, 64200 Uşak, Turkey
}

Keywords: Ilex; Morphometric, UPGMA; Turkey.

\begin{abstract}
The genus Quercus L. has a problematic taxonomy because of widespread hybridization among them. Evergreen Quercus contain three species in section Ilex Loudon namely, $Q$. ilex L., $Q$. coccifera $\mathrm{L}$. and $Q$. aucheri Jaub. et Spach in Turkey. Here, two species, $Q$. coccifera and $Q$. aucheri are usually confused with each other. However, $Q$. coccifera and $Q$. calliprinos are accepted as different species but this subject is still controversial. Morphometric leaf and fruit variations of $Q$. ilex, $Q$. coccifera and $Q$. aucheri in 26 populations were measured for 25 characters. Variations within and among populations of species were detected by cluster analysis and principal component analysis. This study shows that populations of $Q$. coccifera from the south region of Turkey form a second group within $Q$. coccifera. Secondly, $Q$. coccifera show more similarity to $Q$. aucheri than $Q$. ilex, and finally there are two groups within $Q$. coccifera, which may be evaluated as $Q$. coccifera and $Q$. calliprinos.
\end{abstract}

\section{Introduction}

The genus Quercus L., popularly known as oaks shows highest morphological variations among species and populations (Hokanson et al., 1993; Kremer and Petit, 1993), especially its leaf characters are the most valuable in the classification and delimitation of species (Borazan and Babaç, 2003). The major reason for the phenotypic diversification of oaks is the high frequency of hybridization among species (Borazan andBabaç, 2003; Jensen, 1995).

Leaves are good indicators of putative hybridization and oaks can be easily identified by their leaves. The leaves of hybrid species have typically asymmetric shapes and are irregular (Jensen, 1995). Because of common interspecific hybridization in the genus Quercus, individuals that exhibit intermediate morphological characters can be seen widely. Sometimes, it is not possible to identify oak species due to high morphological variation. In this case, acorns are secondary important materials in oaks for classification and determination of hybridization (Jensen, 1988).

In Turkey three evergreen Quercus species exist, viz. Q. aucheri, $Q$. coccifera and $Q$. calliprinos. Q. aucheri is not very widely distributed, it only exists in the south western Anatolia region of Turkey and in the Greek islands like Rhodos. Q. coccifera is confused with $Q$. calliprinos Webb. (Toumı and Lumaret, 2001) because of small or medium shrub formation and acorn shape and evergreen nature. These two species may be evaluated within $Q$. coccifera as $Q$. coccifera subsp. coccifera and Q. coccifera subsp. calliprinos (Webb) Holmboe as two different species. This subject is still controversial (Salvatore and Paola, 1976; Toumı and Lumaret, 2001). $Q$. ilex the last member of Ilex section has two morphological types. These are the rotundifolia type containing small and round leaves and the ilex type containing big pointed leaves. The

*Corresponding author: Email:aykutyilmaza@gmail.com

${ }^{1}$ Department of Biology, Faculty of Science and Arts, Abant Izzet Baysal University, Bolu, Turkey.

DOI: http://dx.doi.org/10.3329/bjpt.v24i1.33004 
rotundifolia morphotype exists in North Africa and the interior region of Spain (Tutın et al., 1964). The ilex morphotype exists along the Atlantic coast of France. These two morphotypes are two different species (Tutın et al., 1964) or two subspecies (Saenz De Rivas, 1967) or only two varieties (Marre, 1961). Additionally, the presence of intermediate forms for these two morphotypes is reported in the Mediterranean region of France and in the north and east coasts of Spain. The aims of the present study were firstly to examine the morphological relationships among the populations sampled and their potential hybrids in Turkey, secondly to designate the status of confused two species, $Q$. coccifera and $Q$. calliprinos, and finally to evaluate and compare results provided from the leaf and acorn character.

\section{Materials and Methods}

The populations sampled are located in the 17 provinces that include the regions of North West, West, South and South West of Turkey. A total of 26 populations belonging to three species of Ilex section, namely Quercus coccifera, $Q$. ilex and $Q$. aucheri were collected. While 16 populations were designated to reveal variations within $Q$. coccifera (Table 1 and Fig. 1). $Q$. aucheri and $Q$. ilex were sampled in 5 populations owing to their distributions in a restricted region.

Table 1. Study populations with population number, location, coordinates and altitude $(\mathrm{C}=Q$. coccifera, $\mathrm{A}=$ $Q$. aucheri, $\mathrm{I}=\mathrm{Q}$. ilex) $\mathrm{Q}$. coccifera (C), $\mathrm{Q}$. aucheri (A) and $\mathrm{Q}$. ilex (I).

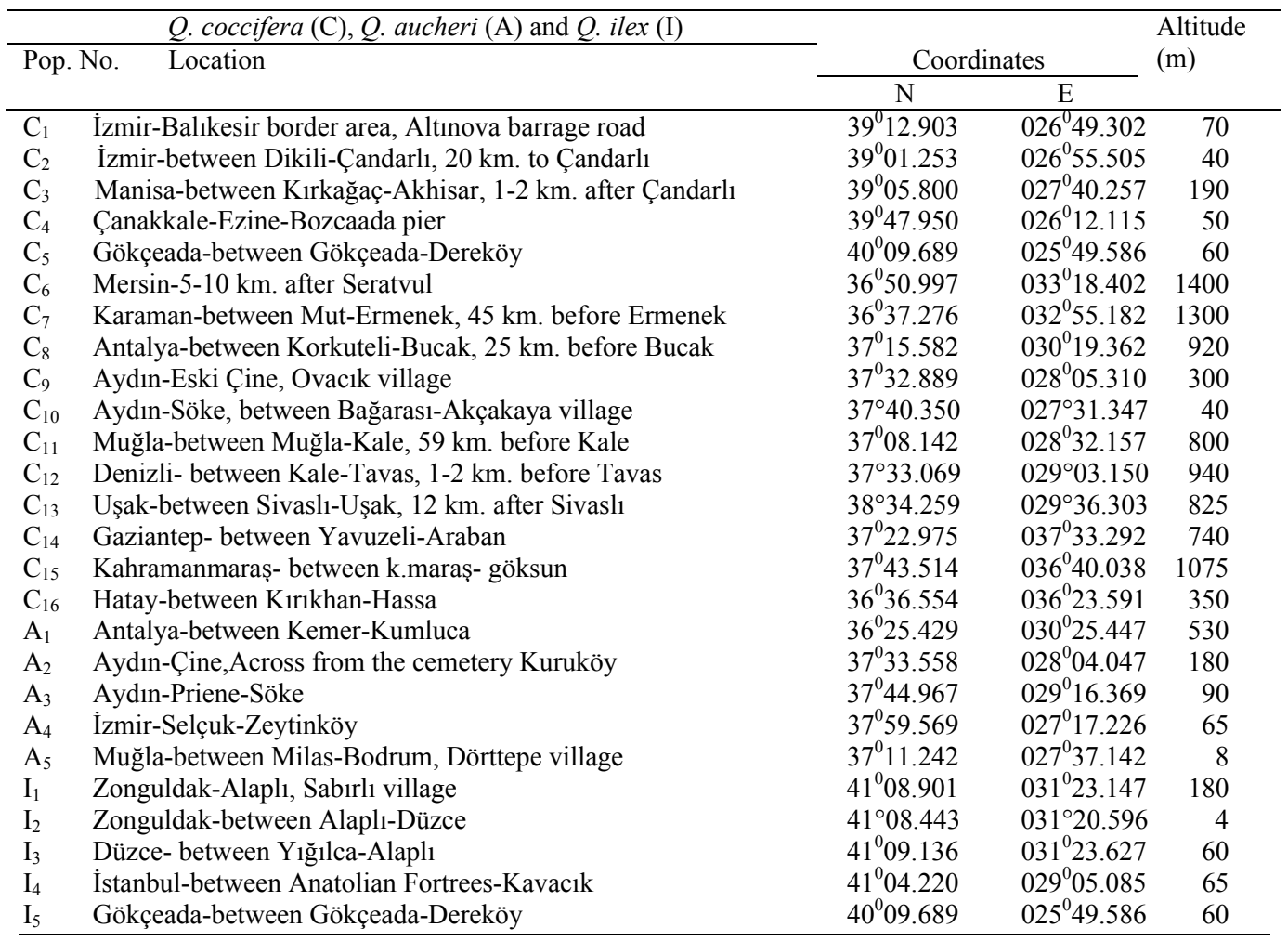




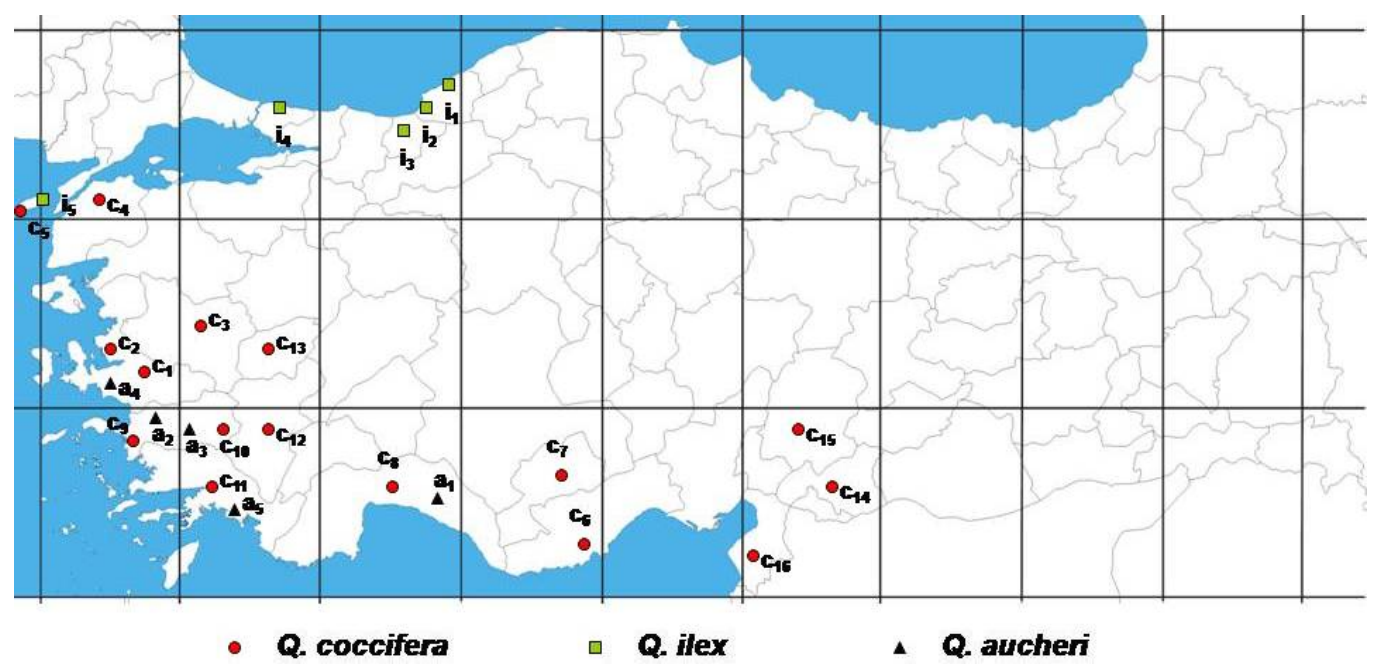

Fig. 1. Distribution of studied populations of $Q$. coccifera, Q. ilex and Q. aucheri in Turkey.

Leaf and fruit samples for identification and statistical analyses of each population were collected from 260 trees. In total, 2600 leaf and fruit materials were measured.All leaf samples were collected at the same height and location after leaf growth had stopped to avoid seasonal and positional variations as reported by Blue and Jensen (1988). Fruit samples were selected from mature acorns and cupules were also used as fruit characters.

Ten characters of leaves (Table 2 and Fig. 2) ad 15 characters from fruits (Table 3 and Fig. 3) were used. Most of the leaf characters were adopted from different sources (Bruschi et al., 2000; Kremer et al., 2002; Borazan and Babaç, 2003; Bruschı et al., 2003; Gonzalez-Rodriguez et al., 2004; Ponton et al., 2004; Boratynsk1 et al., 2008).

Table 2. The leaf characters used in the morphological analysis.

\begin{tabular}{lll}
\hline LL & $:$ & Lamina length \\
PL & $:$ & Petiole length \\
MWL & $:$ & Maximal width of lamina \\
MW & $:$ & Middle width of lamina \\
DTW & $:$ & The distance between the widest point and the leaf tip \\
DBW & $:$ & The distance between the widest point and the leaf base \\
TLL & $:$ & Total leaf length (LL+LP) \\
P\% & $:$ & Petiole length (PL) $\times 100 /$ total leaf length (TLL) \\
MW\% & $:$ & Middle width of lamina (MW) $\times 100 /$ total leaf length (TLL) \\
MWL\% & $:$ & Maximal width of lamina (MWL) x 100/total leaf length (TLL) \\
\hline
\end{tabular}

Table 3. The fruit characters used in the morphological analysis.

\begin{tabular}{llll}
\hline \multicolumn{1}{c}{ Nut characters } & \multicolumn{1}{c}{ Cupsule characters } & \multicolumn{1}{c}{ Stalk characters } & \multicolumn{1}{c}{ Index characters } \\
1. Nut length & 4. Cupule outer diameter & 9. Stalk length & 11. Cupule length/Nut length \\
2. Nut diameter & 5. Cupulethickness & 10. Stalk thickness & 12. Cupule depth/Cupule length \\
3. Nut scar diameter & 6. Cupule scale length & & 13. Nut diameter/Nut length \\
& $\begin{array}{l}\text { (maximum) } \\
\text { 7. Cupule depth }\end{array}$ & $\begin{array}{l}\text { 14. Cupule thickness/Cupule outer } \\
\text { diameter }\end{array}$ \\
& 8. Cupule length & 15. Acorn mass \\
\hline
\end{tabular}


The fruit characters were also selected from literature (Nikoliç and Orloviç, 2002; T1lk1 and Alptekin, 2005). Arithmetic means of all trees were calculated for each character. Then, means of the populations were calculated for each characters. Principal Component Analysis (PCA) and Cluster Analysis (CA) using Statistical version 8.0 were carried out for the analysis of variations in leaf and fruit samples.

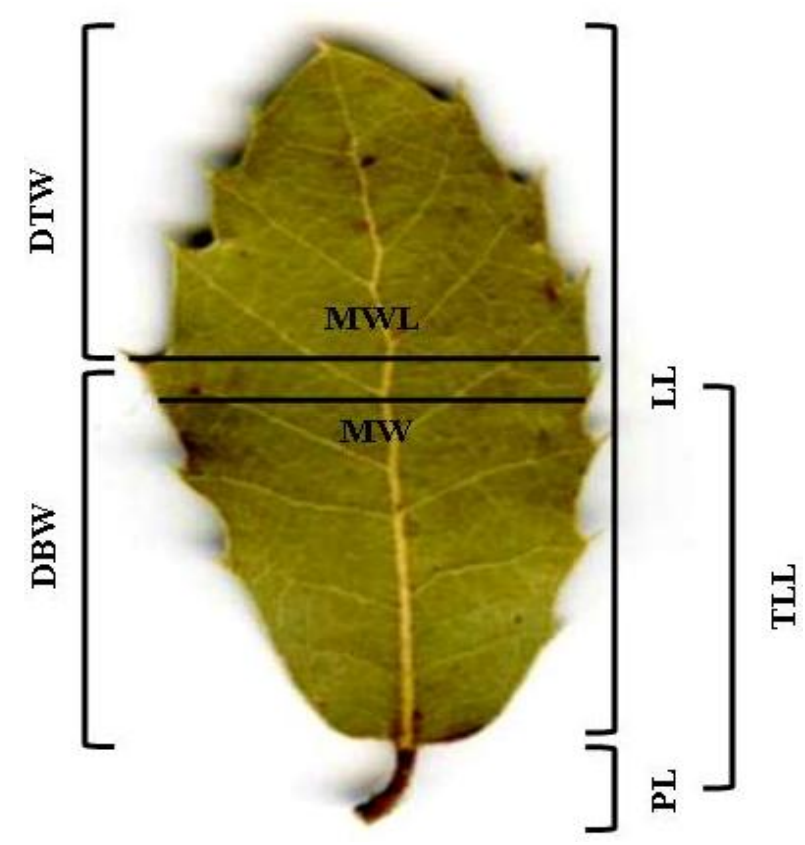

Fig. 2. Morphological leaf characters
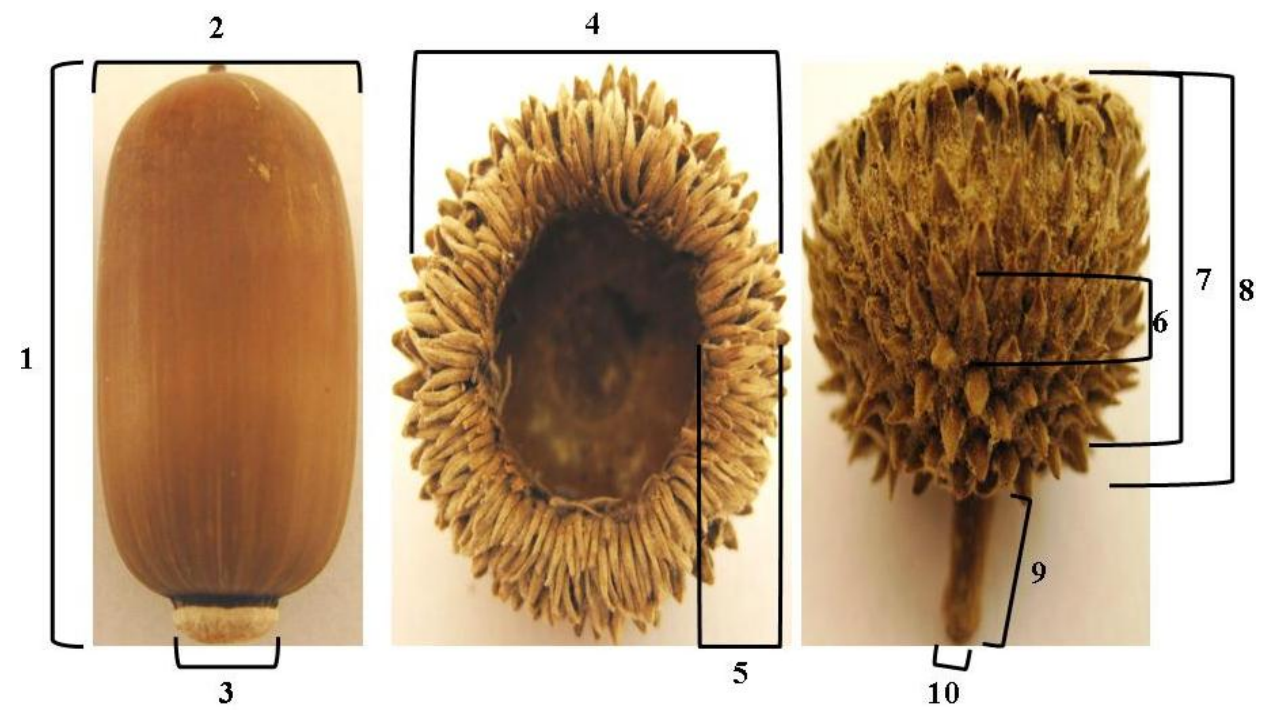

Fig. 3. Morphological fruit characters with character number. 


\section{Results}

The UPGMA cluster analysis performed on the populations for leaf characters recognized two main groups one contains all populations of $Q$. ilex and another group consisted of 21 populations belonging to $Q$. coccifera and $Q$. aucheri. (Fig. 4) When the first group having the populations of $Q$. ilex is evaluated, it can be stated that populations of $Q$. ilex tend to form more morphologically discrete group than $Q$. coccifera and $Q$. aucheri populations and geographically close populations show more similarity like $\dot{I}_{1}$ and $\dot{I}_{2}$ populations (Fig. 4). Differences in geographical distribution are effective on species diversity. The biggest difference in the populations of $Q$. ilex is observed in $\dot{\mathrm{I}}_{5}$ population and the locality of this population is an island in Aegean sea.

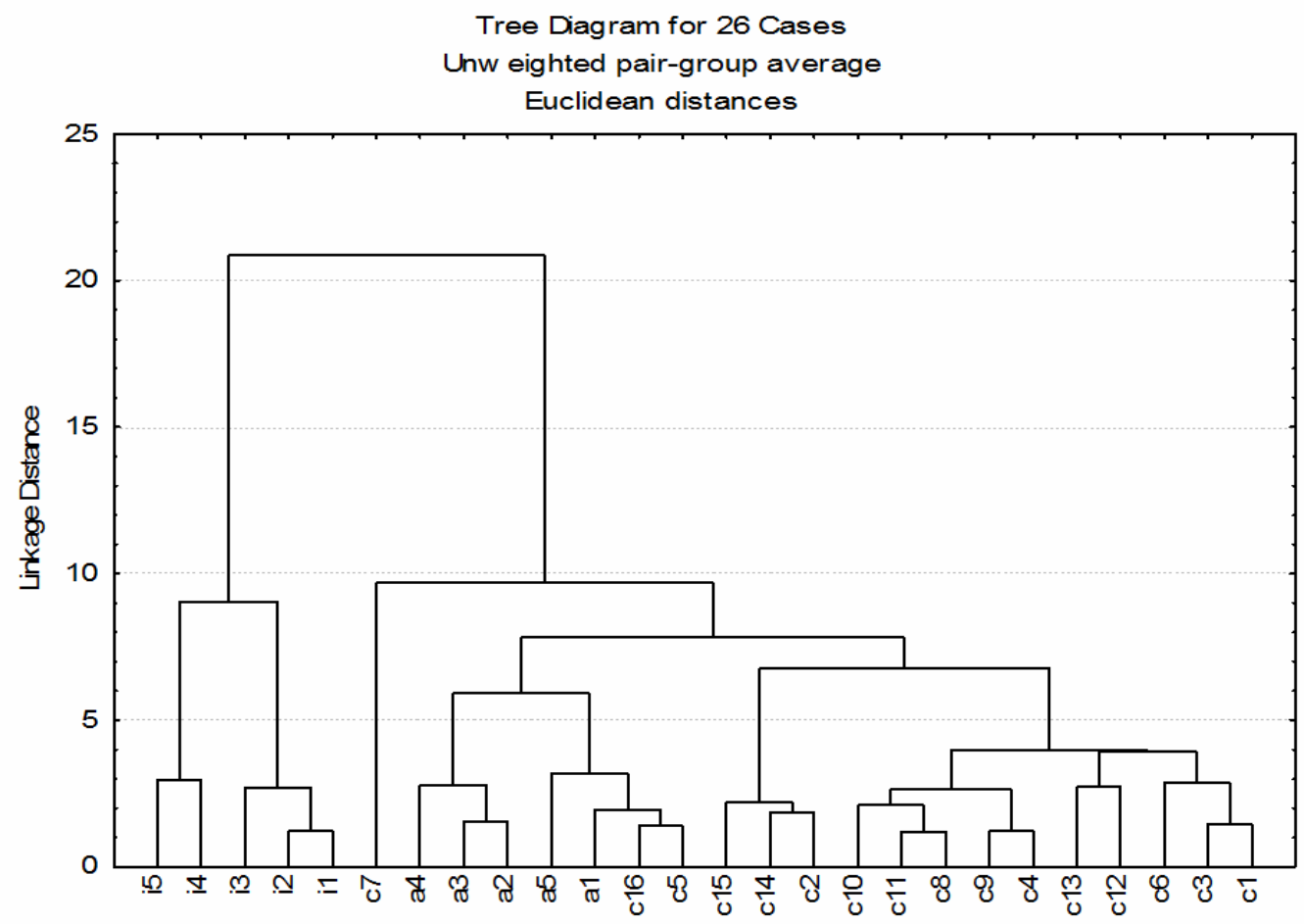

Fig. 4. Phenogram resulting from Cluster Analysis with UPGMA for the leaf materials.

The largest variation in second main group comprising of 21 populations is observed in $\mathrm{C}_{7}$ population of $Q$. coccifera that occurs at high altitude (Table 1 and Fig. 4). Except $\mathrm{C}_{7}$ population, the second main group is divided into two sub-groups, one consists of all populations of $Q$. aucheri and only $\mathrm{C}_{16}$ and $\mathrm{C}_{5}$ populations of $Q$. coccifera, while other sub-group consists of complete populations of $Q$. coccifera (Fig. 4). The highest variation within this sub-group are observed in $\mathrm{C}_{14}, \mathrm{C}_{15}$ and $\mathrm{C}_{2}$ populations. Populations of $Q$. aucheri show the differences from populations of $Q$. coccifera within the second main group but this difference is not clear as in $Q$. ilex.

PCA results (Fig. 5) show the high similarity with CA (Fig. 4) results. PCA analyses clearly separate the $Q$. ilex populations from others. Similarly, two main groups are observed from PCA analysis. While one of these groups consists of populations belonging to $Q$. ilex, other two species are evaluated in the second group. $\mathrm{C}_{14}, \mathrm{C}_{15}$ and $\mathrm{C}_{16}$ populations show the most differences within $Q$. coccifera. Results revealed that fruit characters, $Q$. ilexis is separated from the other two 
species (Figs $6 \&$ 7). CA results show clearly the presence of two main groups. The first main group consists of populations of $Q$. ilex and the second main group consists of the populations of $Q$. coccifera and $Q$. aucheri. This result shows the high similarity with the results of leaves.

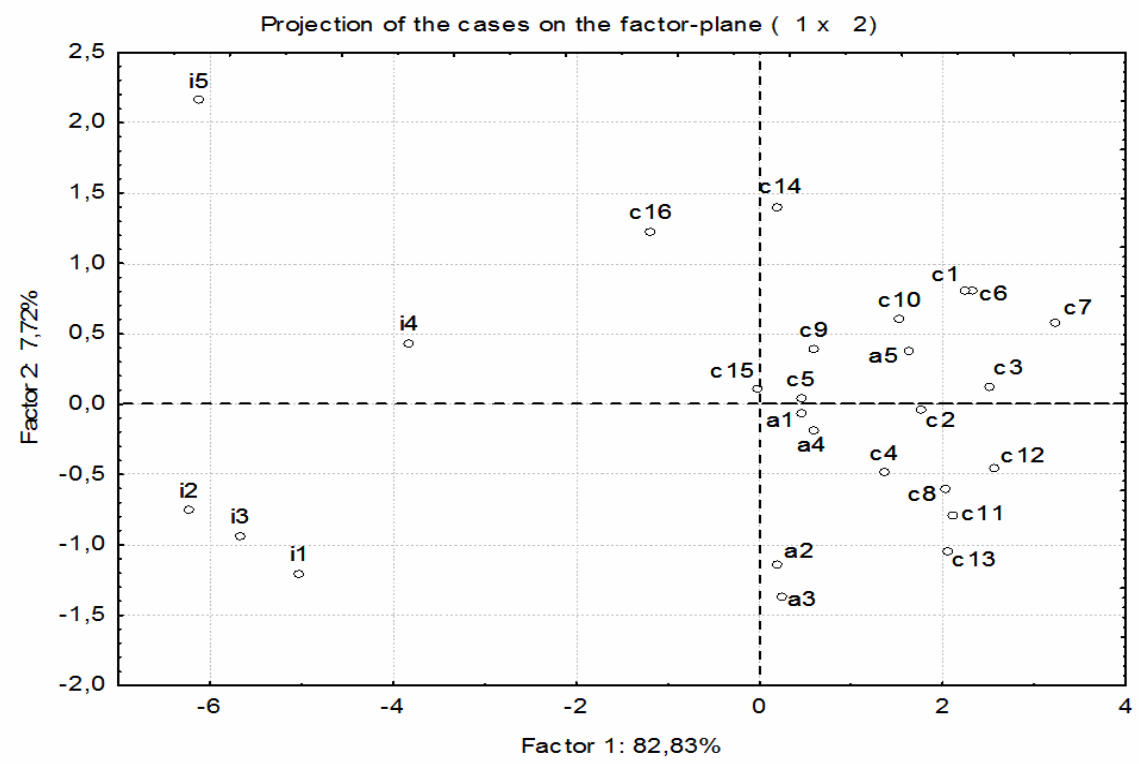

Fig. 5. Resulting projection of Principal Component Analysis for the leaf materials.

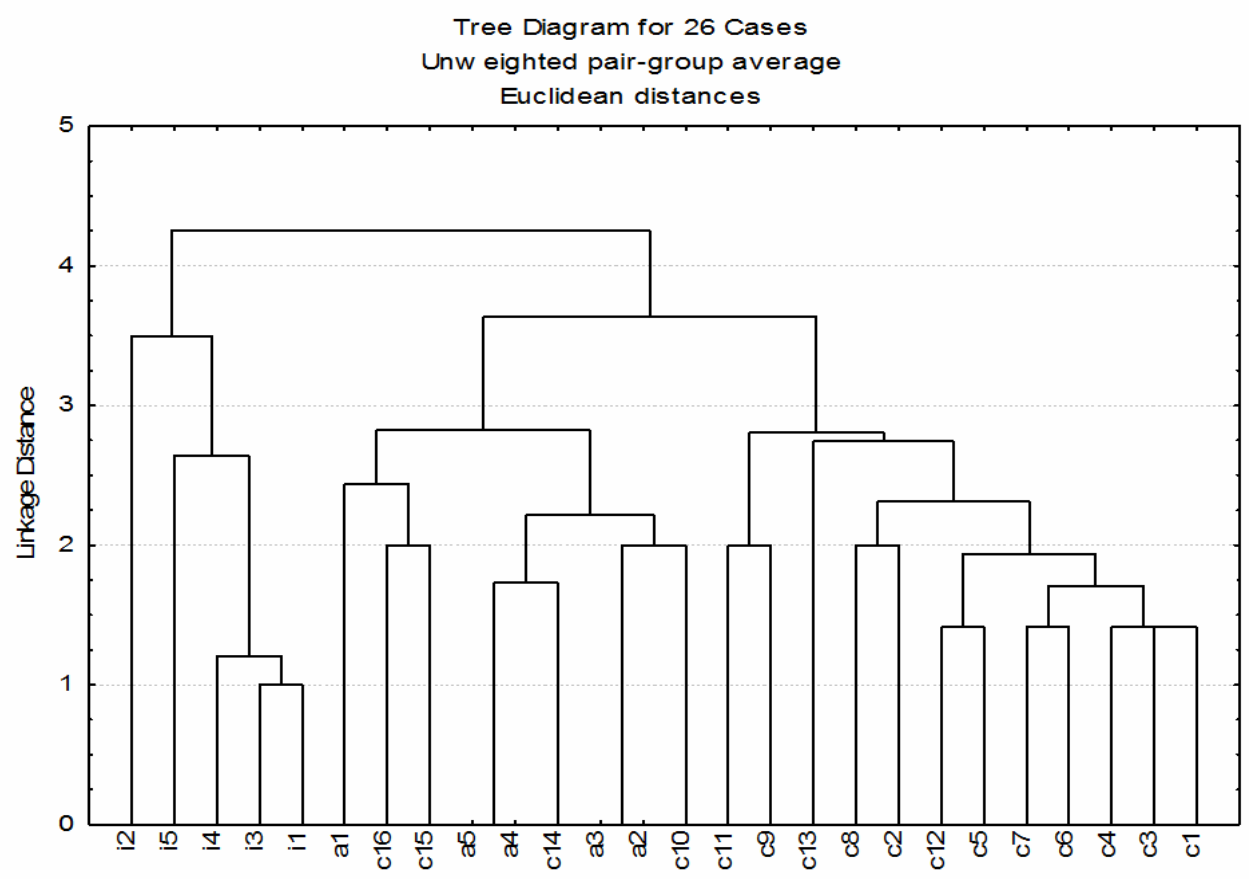

Fig. 6. Phenogram resulting from Cluster Analysis with UPGMA for the fruit materials. 
Populations $\mathrm{C}_{10}, \mathrm{C}_{14}, \mathrm{C}_{15}$ and $\mathrm{C}_{16}$ form a discrete group with Q. aucheri in the $\mathrm{CA}$ graph (Fig. 6). However, remaining populations of $Q$. coccifera form other group (Fig. 6). Similar results showing differences among the species are observed in PCA (Fig. 7).

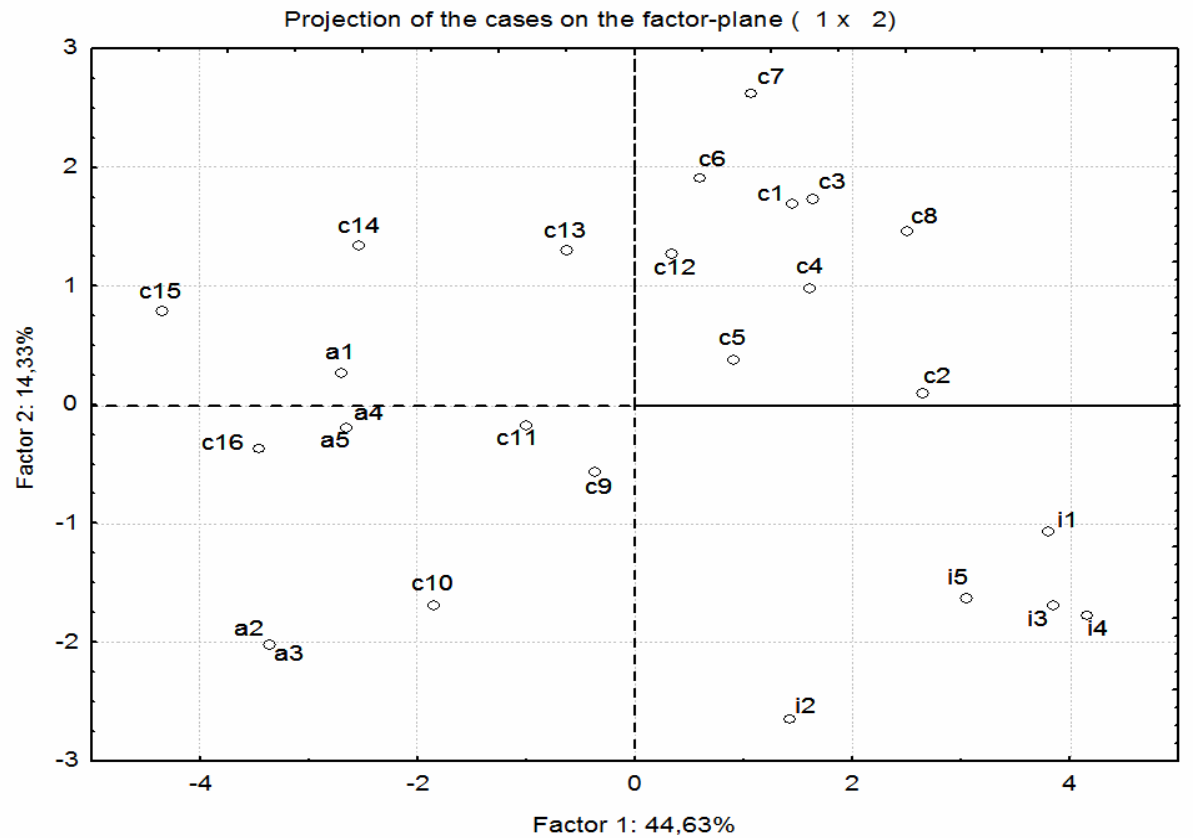

Fig. 7. Resulting projection of Principal Component Analysis for the fruit materials.

\section{Discussion}

The present study revealed that PCA and CA analyses could be used to solve taxonomic problems and to understand the relations among three species belonging to Ilex section of the genus Quercus. Leaf materials were generally used for the comparison of the oaks (Borazan and Babaç, 2003; Bruschı et al., 2003; Ponton et al., 2004; Gonzalez-Rodrıguez and Oyama, 2005; Franjic et al., 2006; Boratynski et al., 2008) but here, for the first time the fruit materials together with the leaf materials were examined in detail.

The results of morphometric studies provided the satisfactory findings for phenetic groupings of taxa in Ilex section. The most significant differences were found on the $Q$. ilex populations. This species was separated from the remaining species on the basis both leaf and fruit. However, $Q$. coccifera populations were grouped next to $Q$. aucheri populations. On the other hand, the results of $Q$. coccifera and $Q$. aucheri are not clearly separated from each other. Especially, due to similar leaf and fruit characters in both taxa, they showed introgression with each other in both CA and PCA plots (Figs 4-7). However, these results draw attention to the presence of a group away from Q. coccifera. The first group consists of the populations sampled from North West, West and South West regions of Turkey. The populations sampled from the south region of Turkey such as $\mathrm{C}_{14}, \mathrm{C}_{15}$ and $\mathrm{C}_{16}$ was included into the second group showing the similarity to the populations of Q. aucheri. Result from the leaf and fruit studies supported these groupings. Similar results are also observed by Salvatore and Paola (1976), Toumı (1995),ToumiandLumaret (2001)and Yilmaz et al.(2013). 
Geographically separation of $Q$. coccifera suggests that there are variation within this species. The restricted group of Q.coccifera located only in the south region of Turkey is geographically closer to Syria, Israel and Palestine. In Palestine there are two subspecies Q. calliprinos Webb. viz. $Q$. calliprinos sub sp. coccifera and $Q$. calliprinos sub sp. calliprinos (Zohary, 1966).

Our results suggested that the two groups showing geographical differences within $Q$. coccifera may be quite possibly strengthen the existence of two species as $Q$. coccifera and $Q$. calliprinos (Y1lmaz et al., 2013).

\section{Acknowledgements}

The authors would like to thank Abant İzzet Baysal University Directorate of Scientific Research Projects (BAP) for providing financial support.

\section{References}

Boratynsk1, A.,Marcysıak, K., Lewandowska, A., Jasınska, A., Iszkulo, G. And Burczyk, J. 2008. Differences in leaf morphology between Quercus petraea and Q. robur adult and young individuals. Silva Fenn. 42: $115-124$.

Borazan, A. and Babaç, M.T. 2003. Morphometric leaf variation in oaks (Quercus) of Bolu,Turkey. Ann. Bot. Fenn. 40: 233-242.

Brusch1, P.,Vendramın, G.G., Busott1, F. And Grosson1, P. 2000. Morphological and molecular differentiation between Quercus petraea and Quercus pubescens (Fagaceae) in Northern and Central Italy. Ann. Bot. 85: 325-333.

Brusch1, P., Vendramın, G.G., Busott1, F. and Grosson1, P. 2003. Morphological and molecular diversity among Italian populations of Quercus petraea (Fagaceae). Ann. Bot. 91: 707-716.

Gonzalez-Rodriguez, A., Arıas, D.M.,Valencia, S. and Oyama, K. 2004. Morphological and RAPD analysis of hybridization between Quercus affinis and Q. laurina (Fagaceae), two Mexican red oaks. Am. J. Bot. 91: 401-409.

Gonzalez-Rodriguez, A. and Oyama, K. 2005. Leaf morphometric variation in Quercus affinis and Q. laurina (Fagaceae), two hybridizing Mexican red oaks. Bot. J. Linn. Soc .147: 427-435.

Hokanson, S.C., Isebrands, J.G., Jensen, R.J. and Hancock, J.F. 1993. Isozyme variation in oaks of the Apostle Islands in Wisconsin: Genetic structure and levels of inbreeding in Quercus rubra and Quercus ellipsoidalis (Fagaceae). Am. J. Bot. 80: 1349-1357.

Jensen, R.J. 1988. Assesing patterns of morphological variation of Quercus spp. in mixed-oak communities. Am. Midl. Nat. 120: 120-135.

Jensen, R.J. 1995. Using leaf shape to identify taxa in a mixed-oak community in land between the lakes, Kentucky. Proc. Sixth Symposium Nat. Hist. lower Tennessee and Cumberland River Valleys 177-188. Center Field Biol., Austin Peay State Univ., Clarksville.

Kremer, A., Dupouey, J.L., Deans, J.D., Cottrell, J., Csa1kl, U., Fınkeldey, R., Espınel, S., Jensen, J., Kleınschmit, J., Van Dam, B., Ducousso, A., Forrest, I., De Heredia, U.L., Lowe, A.J., Tutkova, M., Munro, R.C., Steinhoff, S. and Badeau, V. 2002. Leaf morphological differentiation between Quercus robur and Quercus petraea in stable across western European mixed oak stands. Ann. Forest Sci. 59: 777-787.

Kremer, A. and Petıt, R.J. 1993. Gene diversity in natural populations of oak species. Ann. Forest Sci. 50: 186-202.

Maire, R. 1961. Flore de l'Afrique du Nord, Vol. 7. Ed Lechevallier, Paris.

N1kolic, N.P. and Orlovic, S.S. 2002. Genotypic variability of morphological characteristics of English oak (Quercus robur L.) acorn. Proceeding for Natural Sciences 102: 53-58. 
Ponton, S., Dupouey, J.L. and Dreyer, E. 2004. Leaf morphology as species indicator in seedlings of Quercus robur L. and Q. petraea (Matt.) Liebl.: modulation by irradiance and growth flush. Ann. Forest Sci .61: 73-80.

Saenz De Rivas, C. 1967. Estudios sobre Quercus ilex L., Quercus rotundifolia Lamk. Anales Del Instituto Botanico A. J. Cavanilles 25: 243-262.

Salvatore, G. and Paola, G. 1976. "Quercus calliprinos" Webb e "Quercus coccifera'L.:Ricerche sull'anatomia fogliare e valutazioni tassonomiche e corologiche. Giornale Botanico Italliano 110: 89115.

T1lk1, F. and Alptekın, C.U. 2005. Variation in acorn characteristics in three provenances of Quercus aucheri Jaub. et Spach and provenance, temperature and storage effects on acorn germination. Seed Sci. Technol. 33: 441-447.

Toum1, L. 1995. Etude de la structure genetique et introgressions eventuelles chez les chenes sclerophylles mediterraneens a l'aide de marquers alloenzymatiques. Ph. D. Thesis, University of Aix-Marsielle III, Marsielle.

Toum1, L. and Lumaret, R. 2001. Allozyme characterization of four Mediteranean evergreen oak species. Biochem. Syst. Ecol. 29: 799-817.

Tutın, T.G., Heywood, V.H., Burges, N.A., Moore, D.M., Valentıne, D.H., Walters, S.M. and Webb, D.A. 1964. Flora Europaea. Cambridge University Press, London.

Yılmaz, A., Uslu, E. and Babaç M.T. 2013. Molecular diversity among Turkish oaks (Quercus) using random amplified polymorphic DNA (RAPD) analyses. Afr. J. Biotechnol.12: 6358-6365.

Zohary, M. 1966. Flora Palaestina. Jerusalem Academic Press. Israel. 